\title{
Relationships between off-bottom bivalve aquaculture and the Magellanic steamer duck Tachyeres pteneres in southern Chile
}

\author{
Gonzalo Medina-Vogel ${ }^{1, *}$, Daniel J. Pons ${ }^{1,2}$, Roberto P. Schlatter ${ }^{3, \mp}$ \\ ${ }^{1}$ Centro de Investigación para la Sustentabilidad, Universidad Andres Bello, República 440, Santiago, Chile \\ ${ }^{2}$ Departamento de Matemáticas, Facultad de Ciencias Exactas, Universidad Andres Bello, República 498, Santiago, Chile \\ ${ }^{3}$ Instituto de Ciencias Marinas y Limnológicas, Universidad Austral de Chile, Valdivia, Chile
}

\begin{abstract}
The interactions between aquaculture farms and endemic marine birds in the Northern Hemisphere have been a recurrent topic in the past decades. In the Northern Hemisphere, shellfish aquaculture farms have diverse effects on wildlife populations, and the substantial predation on mussels by birds can lead to culling of the birds by farm managers. In this work, we assessed the interaction between Chilean blue mussel Mytilus chilensis farms and the Magellanic steamer duck Tachyeres pteneres, an endemic duck of southern Chile whose population is thought to be declining. In particular, we assessed the importance of the Chilean blue mussel in the Magellanic steamer duck's diet, and we estimated the magnitude of losses to aquaculture due to predation by the ducks. Between March 1988 and February 1989, observations and sampling collections were performed around a bivalve aquaculture farm in Yaldad Bay (Chiloé Island, Chile). In contrast to what happens in the Northern Hemisphere, we infer that Chilean blue mussel farms do not promote the increase of the Magellanic steamer duck population in Chile: the population dynamics appear to be responding to other habitat variables. Moreover, our estimate for the losses due to predation was less than $1.6 \%$ of the annual farm production in Chile. Despite the fact that sampling was done almost 30 years ago, this study is the most recent one investigating the ecology and social behaviour of the Magellanic steamer duck and its relationship with bivalve aquaculture.
\end{abstract}

KEY WORDS: Chilean blue mussel aquaculture $\cdot$ Magellanic steamer duck - Losses $\cdot$ Quality feeding strategy

\section{INTRODUCTION}

Shellfish aquaculture in Chile, as in other regions of the world, occurs in the intertidal-subtidal shallow nearshore waters, which also tend to harbour the highest densities and diversity of marine birds (Connolly \& Colwell 2005, Dionne et al. 2006, Žydelis et al. 2009). Amongst the marine birds, sea ducks are a group of birds that are particularly likely to interact with shellfish aquaculture, as they are inherently linked to the same areas where most shellfish aquaculture occurs. Sea duck diets include a high proportion of bivalves and crustaceans and

${ }^{*}$ Corresponding author: gmedina@unab.cl

${ }^{\ddagger}$ Deceased some small fish (Del Hoyo et al. 1992), making them potential predators of farmed shellfish, which would consequently negatively affect the economic success of the farm. However, shellfish aquaculture may negatively affect shorebird populations through habitat transformation or exclusion, or by disturbances arising from farming activities and boat traffic (Caldow et al. 2003, Smith \& Shackley 2004, Connolly \& Colwell 2005, Gallardi 2014). Indeed, the interaction between birds and marine farms is a well-documented problem in the Northern Hemisphere (e.g. Dzimbal \& Jarvis 1982, Žydelis et al. 2009, Varennes et al. 2013). 
Despite the fact that the southern region of South America is recognized as having a high marine invertebrate biodiversity, only 1 bird genus is adapted to feed on these: Tachyeres. In contrast, in the Northern Hemisphere, there are at least 8 other genera with such adaptations (e.g. Sanger \& Jones 1982, Whitlach 1982). In southern Chile, the largest Tacherys species is the Magellanic flightless steamer duck T. pteneres, Förster 1844. This marine bird is distributed from Valdivia $\left(40^{\circ} \mathrm{S}\right)$ to Cape Horn $\left(55^{\circ} \mathrm{S}\right)$ and is linked to nearshore intertidal and shallow subtidal habitats (Martínez Piña \& González Cifuentes 2004). It is classified as 'Least Concern' by the IUCN Red List (http://dx.doi.org/10.2305/IUCN.UK.2016-3.RLTS.T 22680033A92839660.en). Although there are no scientific publications about the relationship between birds and shellfish aquaculture in Chile, some studies have investigated the diet of several related coastal birds (e.g. Cursach et al. 2011, Tobar et al. 2011). In Chile, it has been officially accepted that the populations of Magellanic steamer sucks are declining (www. mma.gob.cl/clasificacionespecies/fichas12proceso/ pac/Tachyeres_pteneres_12RCE_INICIO.pdf). Therefore, the aim of this study was to: (1) assess the importance of the Chilean blue mussel in the diet of the Magellanic steamer duck, providing information about population dynamics, and (2) estimate the magnitude of aquaculture losses due to duck predation.

\section{MATERIALS AND METHODS}

\subsection{Study area}

Yaldad Bay is located in the south of Chiloe Island, Chile $\left(43^{\circ} 08^{\prime} \mathrm{S}, 73^{\circ} 44^{\prime} \mathrm{W}\right.$; Fig. 1). Average depth is around $13.4 \mathrm{~m}$, with a maximum of $32 \mathrm{~m}$. The average slope is $2.3 \%$ (maximum $12 \%$ ). The tidal cycle is semidiurnal, with amplitudes ranging from 3 to $5 \mathrm{~m}$. The bay receives freshwater input from 4 rivers (approximately $25 \mathrm{~m}$ wide) and 17 streams, and includes 3 islands (Captuno, Pichiguapi and Linagua; Fig. 1). The mean annual temperature and salinity in the bay are $11.8^{\circ} \mathrm{C}$ and $29.9 \%$. An extensive area of the bay is used for cultivation of Chilean blue mussel Mytilus chilensis (Navarro \& Winter 1982, Ribeiro et al. 2007). Between 1988 and 1989, the aquaculture farm at Yaldad consisted of 84 rafts of $16 \times 16 \mathrm{~m}$, 1 raft of $8 \times 8 \mathrm{~m}$ and 64 floating longlines, each $100 \mathrm{~m}$ long. Seeded long lines are installed in October and moved in early March onto grow-out ropes. Harvesting of commercial mussels occurs 8 to 12 mo later,

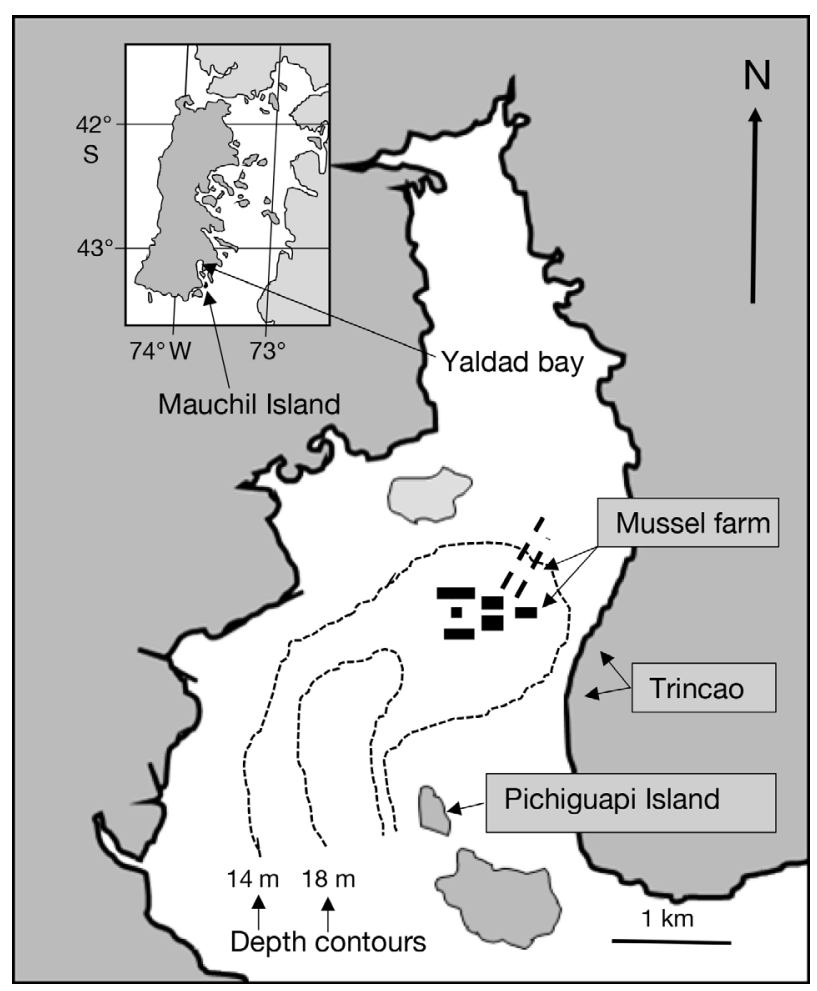

Fig. 1. Geographic location of Yaldad Bay and Mauchil Island, Chile, and the 3 study polygons: mussel farm, Trincao seashore and Pichiguapi Island

when they are $>5 \mathrm{~cm}$ long. The most productive growth period of the year is between September and February, a period that includes gamete formation and spawning (December-January) (Navarro \& Winter 1982). The seashore intertidal area is mostly stony and muddy, and the sea bottom at the mussel farm is soft sediment. All sites are characterized by a temperate-humid-cool climate with 2000-3000 mm of precipitation $\mathrm{yr}^{-1}$, and an average humidity around $90 \%$. The average annual temperature is $<10^{\circ} \mathrm{C}$ (Toledo \& Zapater 1989). As control study sites, the area surrounding Mauchil Island and the south section of the Coldita channel were selected (Fig. 1); the island extension is $1.2 \mathrm{~km}^{2}$, it is located $15 \mathrm{~km}$ south of Yaldad Bay $\left(43^{\circ} 15^{\prime} 26^{\prime \prime} \mathrm{S}, 73^{\circ} 40^{\prime} 19^{\prime \prime} \mathrm{W}\right)$ and is accessible by navigating the Coldita channel waterway.

\subsection{Assessment of the Magellanic steamer duck population}

Three trips to select the study sites, determine the observation methods and choose rafts to be monitored were made between December 1987 and February 1988. Thereafter, from March 1988 to February 
1989, 12 censuses at the $M$. chilensis farm in Yaldad Bay and the closed seashores of Pichiguapi Island and Trincao were made. A total of $292 \mathrm{~h}$ of observations were completed: 102 at Trincao, 102 in the farm area and 88 at Pichiguapi Island.

Duck surveys within Yaldad Bay were conducted once per month from 06:00-18:00 h. Ducks were observed during daylight from a moving inflatable boat following the bay contour at no more than $100 \mathrm{~m}$ from shore at medium speed $\left(3\right.$ knots $\left.\mathrm{h}^{-1}\right)$, with $7 \times 42$ binoculars and with a team of 1 driver/observer with a data recorder (Žydelis et al. 2009). An appropriate distance from the birds and suitable vessel speed were maintained to reduce the probability of ducks moving away. A total distance of 8.5 nautical miles was covered daily within, on average, $3 \mathrm{~h}$ (08:0011:00 h). Thereafter, within the study area at Yaldad Bay, 3 study polygons were selected: (1) the mussel farm (2) the Trincao seashore and (3) the Pichiguapi Island seashore (Fig. 1). The observations in these 3 polygons were performed on 3 consecutive days on the rafts at the mussel farm, and hiding in the vegetation close to the sea at Trincao (Trincao polygon) and Pichiguapi Island (Pichiguapi polygon).

All birds in those polygons were counted, and their activity (feeding, agonistic, resting and moving) was recorded. On 5 occasions (May, June, November, January and February), a census at the control study site Mauchil Island (Fig. 1) was performed by walking the entire perimeter, counting all birds at no more than $200 \mathrm{~m}$ from shore with $7 \times 42$ binoculars. Each census was completed between 08:00 and 11:00 h. No steamer duck observations were performed in October 1988 and December 1989 due to poor weather conditions.

\subsection{Diet assessment of Tachyeres pteneres}

Duck diet was inferred by identifying potential food sources for ducks in each polygon. For this purpose, relevant data were obtained by diving and searching for duck prey at the sea bottom in the intertidal and subtidal zones, by observing the feeding behaviour of the ducks and by shooting randomly selected ducks in the different study polygons. Fifteen ducks were shot and transported to the mussel farm laboratory at Yaldad Bay to be dissected and prey items found in the gullet, proventriculus and gizzard were then recorded. Shooting was done with a licence from the Servicio Agricola y Ganadero, Ministry of Agriculture, Chile. Dissections were performed according to Wobeser \& Spraker (1987). The number and size of mussels eaten was inferred by counting the total number of umbos and by measuring the shell length of uncrushed mussels found in the digestive tracts.

According to the farm workers, ducks did not predate the inside vertical ropes of rafts, only the exterior ones; this was also the case for the hanging submerged ropes or seed collectors of the longlines. These observations were confirmed during our study. To assess the losses from predation, we measured the weight of selected hanging submerged ropes from 2 randomly selected rafts. Among all hanging submerged ropes in each raft, we tagged 100 external ropes, all of which were located within 4 parallel lines from outside to inside; 20 intermediate ropes were considered as barriers, and 10 internal ropes were used as controls. Each vertical rope was weighed 6 times during the study to compare weight gained or lost. Furthermore, in each month, we collected randomly selected mussel samples from natural populations and from the longline population within Yaldad Bay in order to compare their size and resistance to compression $\left(\mathrm{kg} \mathrm{cm}^{-2}\right)$ with calibrated equipment at the College of Engineering, Universidad Austral de Chile. Mussels were sampled from a section of $30 \times 30 \mathrm{~cm}$ width at a depth of about $1 \mathrm{~m}$ below low tide.

\subsection{Duck feeding behaviour}

A main assumption was that Magellanic steamer ducks are diurnal, so in order to support this assumption, flocks at the mussel farm were followed all night long on 4 occasions. No birds were seen foraging after sunset, similar to what has been observed in other species of marine birds (Guillemette 1998). To estimate the proportion of time that ducks dedicate to feeding, observations started after first light, starting in general at 08:00 $\mathrm{h}$ and finishing at 18:00 h. Ducks within the polygons were observed every $10 \mathrm{~min}$, and their activity (feeding, resting and interacting) was registered in intervals of 2 min. Feeding time was described as the proportion of total time (h) that ducks were feeding (diving, probing the substrate in search of prey, ingesting, searching or eating around seaweed banks at the sea or in ground) in relation to the the total time that ducks were observed. Tide times and depth were determined using the tide table of the Nautical Almanac of the Instituto Hidrográfico de la Armada de Chile. These observations were repeated for Mauchil Island on 5 occasions (May, June, November, January and February). 


\subsection{M. chilensis losses}

To estimate $M$. chilensis losses at the mussel farm due to Magellanic steamer ducks between March 1988 and February 1989, we built up a simple mathematical model that considered (1) an estimate of the number of single blue mussels a duck can eat per day taking into account the growth pattern of $M$. chilensis at the farm in Yaldad Bay; (2) the number of ducks that visited the farm per month and (3) the wet weight of a blue mussel when harvested.

The growth pattern of $M$. chilensis at the farm was inferred from the data presented in Table 1, which represent random samples from the submerged ropes at the farm at no more than $50 \mathrm{~cm}$ depth; this sampling was performed for $1 \mathrm{yr}$, from March 1988 to February 1989. Using allometric principles (e.g. see Von Bertalanffy 1969), the average wet weight per month $(W, g)$ and the average length per month $(L$, $\mathrm{cm})$ were correlated using:

$$
W=k L^{\alpha}
$$

where the constants $k$ and $\alpha$ must be determined. This equation has been successfully used in physiological investigations and applied in the management of mussel production (Gosling 1992, Mondol et al. 2016). Once the allometric relation is established, shell measurement or growth is sufficient to estimate biomass and flesh production. In turn, according to the data in Table 1, the average length behaves as a linear function of time, namely:

$$
L(t)=A+B t
$$

where the constants $A$ and $B$ must be determined, $t$ is measured in months, and $t=0$ corresponds to the beginning of the first month of the farming season, namely March. Combining both relations, an equation for the average wet weight as a function of time can be obtained:

$$
W(t)=k(A+B t)^{\alpha}
$$

The average wet weight of a 1 yr old blue mussel at harvest is given by $W(12)$.

Regarding the number of ducks and the amount of M. chilensis (weight in grams) that they can consume daily during different months of the year at the farm, no global reasonable function of time $t$ seemed to be available, since the feeding behaviour of Magellanic steamer ducks in relation to $M$. chilensis depends on many factors. To circumvent these difficulties, an estimate of the number of ducks present at the farm during each day of month $t$, which we denote by $D(t)$, was inferred from the observations (Table 1). The weight ( $g$ ) of $M$. chilensis that a single bird can eat per day was assumed to be $C=97.4 \mathrm{~g} \mathrm{~d}^{-1}$, the maximum recorded in 1 digestive tract (Table 2). With these considerations, the estimate for the annual $M$. chilensis losses at the farm is indeed an upper bound, a priori a pessimistic scenario for the economic success of the farm.

The upper bound for the number of $M$. chilensis eaten by a duck at the farm during month $t$ is given by the function:

$$
\varphi(t)=31 \int_{t}^{t+1} \frac{C}{W(s)} \mathrm{d} s
$$

Table 1. Average length and weight of blue mussels Mytilus chilensis haphazardly collected from March 1988 to February 1989 from the rafts' hanging ropes at no more than $50 \mathrm{~cm}$ depth and Magellanic steamer ducks counted at the farm in Yaldad Bay in the corresponding

\begin{tabular}{|c|c|c|c|c|c|c|c|}
\hline \multirow[t]{2}{*}{ Month } & \multirow[t]{2}{*}{$\mathrm{N}$} & \multicolumn{2}{|c|}{ Length (mm) } & \multicolumn{2}{|c|}{ Weight (g) } & \multirow{2}{*}{$\begin{array}{l}\text { Comparison } \\
\text { length (mm) }\end{array}$} & \multirow{2}{*}{$\begin{array}{l}\text { No. of } \\
\text { ducks }\end{array}$} \\
\hline & & Mean & $\mathrm{SD}$ & Mean & $\mathrm{SD}$ & & \\
\hline Mar & 26 & 11.8 & 0.23 & 1 & 0.10 & No data & 9.9 \\
\hline Apr & 32 & 13.8 & 0.34 & 1 & 0.15 & No data & 17.1 \\
\hline May & 36 & 15.8 & 0.20 & 2 & 0.19 & No data & 33.9 \\
\hline Jun & 45 & 17.8 & 0.21 & 2 & 0.30 & No data & 7.5 \\
\hline Jul & 74 & 19.7 & 0.12 & 3 & 0.22 & No data & 4.2 \\
\hline Aug & 48 & 29.5 & 0.10 & 4 & 0.14 & 24.2 & 1.8 \\
\hline Sep & 32 & 39.4 & 0.35 & 5 & 0.24 & 27.1 & 17.3 \\
\hline Oct & 34 & 44.9 & 0.40 & 9 & 0.33 & 33.4 & $10.6^{\mathrm{a}}$ \\
\hline Nov & 22 & 50.3 & 0.25 & 20 & 0.30 & 41.4 & 3.8 \\
\hline Dec & 45 & 55.5 & 0.46 & 20 & 0.22 & 47.9 & $2.1^{\mathrm{a}}$ \\
\hline Jan & 76 & 60.7 & 0.12 & 20 & 0.12 & 48.8 & 0.4 \\
\hline Feb & 12 & 66.9 & 0.48 & 30 & 0.42 & No data & 2.5 \\
\hline
\end{tabular}
month. Comparison length: for comparison, first-year lengths of $M$. chilensis at the Yaldad farm from 1982 are shown (data from Navarro \& Winter 1982). N: number collected where we considered 31 to be the average number of days in a month. Note that $\varphi(t)$ is a decreasing function of $t_{\text {; }}$ indeed, the amount of $M$. chilensis equivalent to $C=$ $97.4 \mathrm{~g}$ decreases since the average weight function $W(t)$ is increasing. We infer that the number of $M$. chilensis eaten by all ducks present at the farm during month $t$ is at most:

$$
N(t)=D(t) \times \varphi(t)
$$

and the total number of $M$. chilensis eaten by the ducks in $1 \mathrm{yr}$ is:

$$
M=\sum_{t=0}^{11} N(t)
$$

Finally, the upper bound for the annual $M$. chilensis losses in grams at the farm is the number $W(12) \times M$. 


\subsection{Data analysis}

Data from the observations on duck feeding behaviour were neither normally distributed nor independent. Non-parametric Kruskal-Wallis and Mann-Whitney statistics tests were used to assess significance between study variables (duck population trends, time spent feeding, weight variations and differences in hanging submerged ropes); significance was set at $\alpha=0.05$. Thereafter, a Pearson correlation matrix was used to assess correlations between tide, agonistic events and feeding time. Regarding the strength of the shells, a non-parametric Mann-Whitney U-test was used, since even after log10 transformation, the data did not correspond to a normal distribution (skewness -0.91, kurtosis -0.89). Log-log and linear regressions were used to model the growth of mussels (that were haphazardly and independently chosen) with an excellent correlation. Data processing and analysis were performed in SYSTAT 12 and Excel.

\section{RESULTS}

We counted (mean \pm SD) $19 \pm 3.6$ ducks at Pichiguapi Island, $6.4 \pm 4.2$ at Trincao and $10 \pm 4.5$ at the farm. The Pichiguapi Island study site significantly concentrated the major number of ducks (68.6 \pm 43.5); instead of Yaldad bay (55.3 \pm 16.6) (KruskalWallis test: $\left.H_{2}=6.226, \mathrm{p}=0.04\right)$. Only the Trincao study polygon recorded variation throughout the year $\left(H_{2}=6.0, \mathrm{p}<0.05\right.$; Pichiguapi: $H_{2}: 4.4, \mathrm{p}=0.11$; farm: $H_{2}=3.7, \mathrm{p}=0.15$; Fig. 2). Nevertheless, the largest number of steamer ducks was recorded between March and May 1988, declining towards the rest of the year $\left(H_{2}=8.8, \mathrm{p}=0.01\right)$. The population recorded at Yaldad Bay was $55.3 \pm 16.6$ ducks while at Mauchil Island it was $68.6 \pm 43.5$ ducks, with no significant variations during the year. This low variation of the population over time at the study sites shows a pattern of low mobility, mostly associated with a territorial and non-migrant species (Martínez Piña \& González Cifuentes 2004).

Most pairs with ducklings were registered between December and March. These stable pairs of adult males and females concentrated along seashores near freshwater streams that provide a defense against flocks of solitary individuals; in fact, only on a few occasions did stable pairs come close to the farm area. In Yaldad Bay, stable pairs constituted $38 \%$ of the population, solitary adult males $2 \%$ and flocks $60 \%$. Similarly, at Mauchil Island, stable pairs comprised $44 \%$ of the population, solitary adult males $2 \%$ and flocks $54 \%$. Those steamer ducks using the mussel farm polygon belonged mostly to flocks, which permanently moved in and out of the installations; only rarely were ducks from flocks observed resting at the seashore, and this occurred only at Pichuhuapi Island. In contrast, pairs of adult ducks associated with seashores were resting and preening on land every day.

The daily average time spent feeding at the mussel farm was $16 \%\left(1.3 \mathrm{~h} \mathrm{~d}^{-1}\right)$, of which $4 \%\left(0.1 \mathrm{~h} \mathrm{~d}^{-1}\right)$ was at the rafts, $30 \%\left(2.4 \mathrm{~h} \mathrm{~d}^{-1}\right)$ at Trincao and $42 \%$ (3.2 $\left.\mathrm{h} \mathrm{d}^{-1}\right)$ at Pichiguapi Island. When ducks in the farm area were not feeding, they were either moving or resting on the longline buoys. Moreover, from the total time that a single pair of ducks was followed at Yaldad Bay (250 additional hours), they spent $16 \mathrm{~h}(6 \%)$ feeding at the mussel farm, $24 \mathrm{~h}$ $(10 \%)$ at Trincao and $38 \mathrm{~h}(15 \%)$ at Pichiguapi Island, showing a significant difference between the 3 studied polygons $\left(H_{3}=11.3, \mathrm{p}=0.01\right)$. In comparison, at Mauchil Island, the observed time that the ducks spent feeding was $41 \%$, very similar to Pichiguapi Island.

We recorded 521 diving events, lasting an average of $29 \mathrm{~s}$ (5-71 s) and no significant differences between the studied polygons.

Regarding the total population per day and the time birds spent feeding (predation intensity: population $\times$ hours spent feeding), it was higher at Pichiguapi Island $\left(H_{2}=11.9, \mathrm{p}<0.01\right)$ than in the other 2 studied polygons (Fig. 3). In addition, the results from the farm showed no preferences of ducks for feeding either on the submerged ropes hanging on the rafts or those hanging on the longlines. Predation within the farm area was not constant during the year.

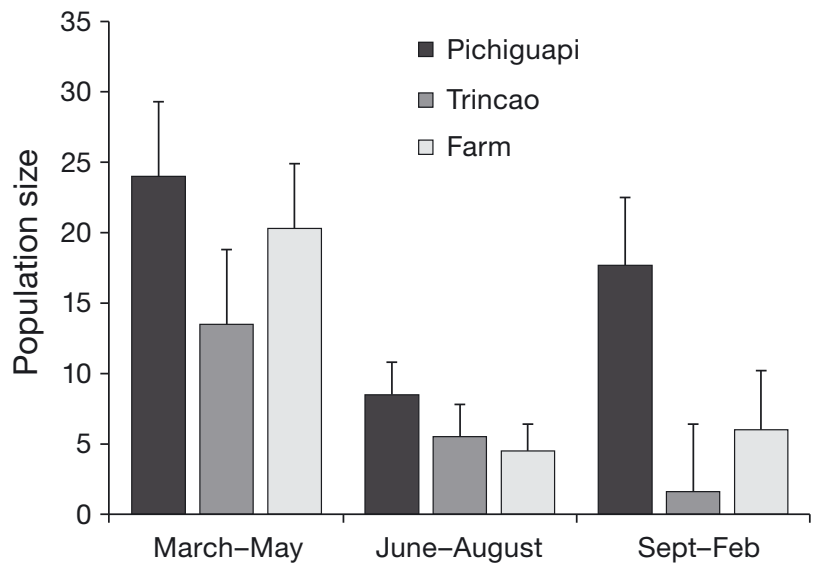

Fig. 2. Mean \pm SE population size of flightless steamer ducks counted at the 3 study polygons within Yaldad Bay 


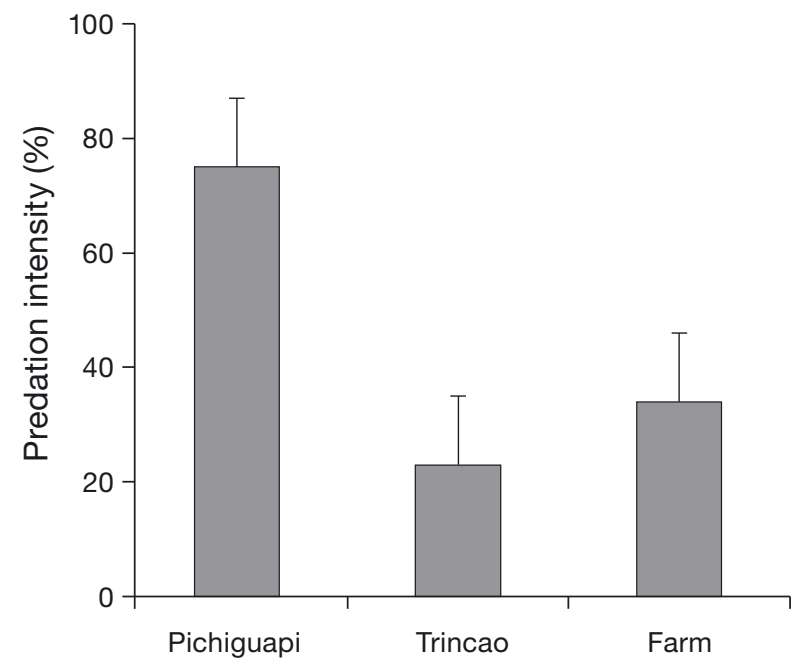

Fig. 3. Mean \pm SE predation intensity (population $\times$ hours spent feeding) as a percentage of the total observation time that steamer ducks spent at the 3 study polygons within Yaldad Bay between March 1988 and February 1989

We randomly collected 482 blue mussels from the farm and 290 blue mussels from natural populations over $7 \mathrm{mo}$. On average, their length varied from 20.3 to $54.3 \mathrm{~cm}$, and strength varied from 7.3 to $30.3 \mathrm{~kg} \mathrm{~cm}^{-2}$. Among all samples, there was no difference between the length of the mussels collected at the farm (35.5 $\mathrm{cm}$ average) and those collected from natural populations ( $34.7 \mathrm{~cm}$ average). However, shells of mussels collected from natural populations were significantly $\left(U_{1}=0.0, \mathrm{p}<0.01\right)$ more resistant to compression ( $45.6 \mathrm{~kg} \mathrm{~cm}^{-2}$ on average) than those from the farm $\left(20.4 \mathrm{~kg} \mathrm{~cm}^{-2}\right.$ on average). There was a close to significant negative correlation between the population of Tachyeres pteneres at the farm and the Mytilus chilensis growth pattern during the year (Pearson correlation matrix: -0.6; $\mathrm{p}=0.07$ ): the larger the mussels were, the smaller the number of ducks using the farm area. Moreover, the larger $M$. chilensis were at the farm, the less time T. pteneres spent feeding (Pearson correlation matrix: $-0.7 ; \mathrm{p}<0.01)$ : indeed, the intensity of predation at the longlines decreased from March to February (Fig. 3).

Regarding tidal effects (Fig. 4), ducks spent significantly more time feeding at low tide outside the farm area at Trincao (Mann-Whitney $U_{1}=18.0, \mathrm{p}=0.02$ ) and Pichuguapi Island $\left(U_{2}=0.0, \mathrm{p}<0.01\right)$. In contrast, at the farm, a longer time feeding was registered at high tide, with a close to significant difference $\left(U_{1}=\right.$ $73.5, \mathrm{p}=0.07$ ).

Within all analysed digestive tracts, 51 undigested blue mussels were found, with an average length of $16.6 \mathrm{~mm}$ (range: 5-65 $\mathrm{mm}$ ). In 5 birds, there were no

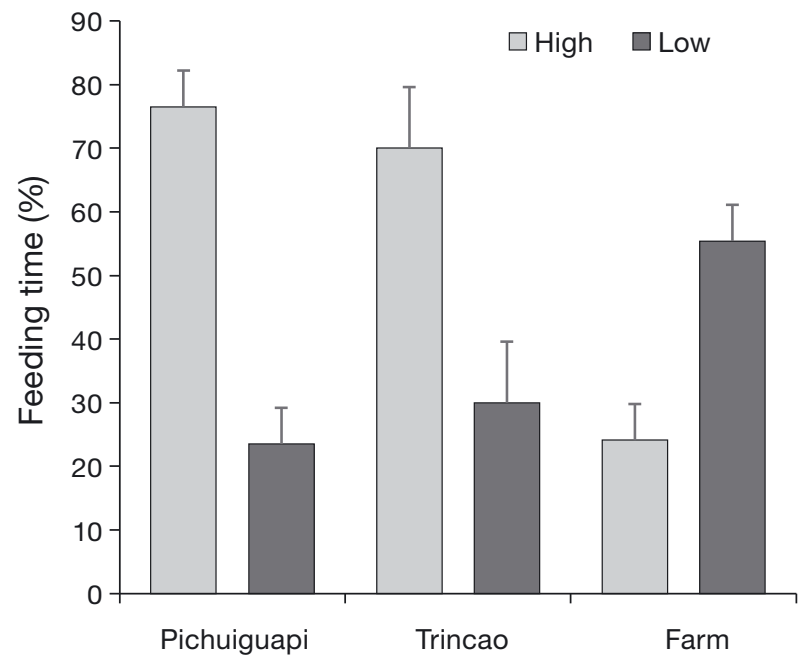

Fig. 4. Mean \pm SE of total observation time that flightless steamer ducks dedicated to feeding during high and low tide at each study site within Yaldad Bay between March 1988 and February 1989

mussels inside their digestive tracts, but crustacean remains were found instead. The heaviest bivalve content $(97.4 \mathrm{~g})$ in a single $T$. pteneres was recorded at the farm. The average wet weight of the digestive tract contents was $45.3 \mathrm{~g}$, of which $23.8 \mathrm{~g}(53 \%)$ corresponded to bivalves. In individual digestive tracts with mussel content, 1 to $68 \mathrm{M}$. chilensis were recorded (Table 2).

With respect to the hanging submerged ropes at the selected study rafts, all increased their initial weights by 5.8 to 5.9 times, with no significant difference between the outside, middle and inside ropes.

Mussels were the most predominant dietary item recorded in the digestive tracts at every location: at Trincao, $78 \%$ of the total wet weight were mussels and only $22 \%$ crustaceans, giving a ratio of 3.54 , compared to a ratio of 6.14 at Mauchil Island and 1.63 at the mussel farm. The digestive contents included several species of crustaceans (Munida subrugosa, Cancer edwardsi, C. coronatus and undetermined amphipods), as well as mussels (M. chilensis, Aulacomya ater, Tagelus dombeii and undetermined species).

We found no relationship between human activity at the farm and the time the ducks spent feeding therein. As explained in Section 2.5, we provide an equation based on allometric principles for the average wet weight, $W(t)$, of $M$. chilensis (Eq. 3), where $k_{\text {, }}$ $A, B$ and $\alpha$ must be determined from the data randomly collected from the vertical ropes at the farm (see Table 1). In the first step, assuming Eq. (1), we performed a log-log-linear regression to obtain $k=$ $1.314 \times 10^{-3}$ and $\alpha=2.3813\left(R^{2}=0.946\right)$. 
Table 2. Characteristics and wet weight of digestive tract contents of Magellanic steamer ducks captured in Yaldad Bay and Mauchil Island between March 1988 and February 1989. Total body length includes tail length

\begin{tabular}{|c|c|c|c|c|c|c|c|c|c|}
\hline Month & Site & Sex & $\begin{array}{c}\text { Body } \\
\text { weight } \\
(\mathrm{kg})\end{array}$ & $\begin{array}{l}\text { Total body } \\
\text { length } \\
(\mathrm{cm})\end{array}$ & $\begin{array}{c}\text { Tail } \\
\text { length } \\
(\mathrm{cm})\end{array}$ & $\begin{array}{r}\text { Digestive tract } \\
\text { Crustaceans }\end{array}$ & $\begin{array}{c}\text { content }(g) \\
\text { Bivalves }\end{array}$ & $\begin{array}{c}\text { No. of } \\
\text { blue mussel } \\
\text { umbos }\end{array}$ & $\begin{array}{c}\text { Minimum } \\
\text { no. of blue } \\
\text { mussels }\end{array}$ \\
\hline \multirow[t]{2}{*}{ March } & \multirow[t]{2}{*}{ Farm } & Male & 5.2 & 77.0 & 8.3 & 38.2 & 0 & & \\
\hline & & Female & 2.1 & 64.3 & 1.5 & 12.3 & 9.1 & 82 & 41 \\
\hline \multirow[t]{4}{*}{ April } & \multirow{3}{*}{$\begin{array}{l}\text { Trincao } \\
\text { Farm }\end{array}$} & Male & 5.9 & 74.0 & 9.6 & 21.1 & 27.6 & 12 & 6 \\
\hline & & Female & 4.4 & 74.0 & 8.8 & 22.2 & 21.5 & 136 & 68 \\
\hline & & Female & 5.3 & 77.0 & 8.7 & 8.3 & 55.5 & 85 & 43 \\
\hline & Trincao & Male & 6.1 & 80.0 & 10.0 & 29.7 & 33.7 & 2 & 1 \\
\hline \multirow[t]{4}{*}{ May } & Mauchil & Male & 4.2 & 25.5 & 9.8 & 35.1 & 0 & & \\
\hline & Trincao & Male & 5.0 & 29.3 & 7.5 & 30.1 & 16.2 & 2 & 1 \\
\hline & Farm & Male & 5.0 & 76.5 & 5.5 & 6.3 & 51.7 & 13 & 7 \\
\hline & Trincao & Female & 4.1 & 71.5 & 6.0 & 10.2 & 33.6 & 20 & 10 \\
\hline \multirow[t]{3}{*}{ July } & Mauchil & Female & 3.9 & 71.0 & 8.7 & 42.1 & 0 & & \\
\hline & Trincao & Male & 4.8 & 73.5 & 6.8 & 6.3 & 97.4 & 11 & 6 \\
\hline & Farm & Male & 5.4 & 80.1 & 9.2 & 30.4 & 11.2 & 76 & 38 \\
\hline \multirow[t]{2}{*}{ November } & Mauchil & Male & 4.9 & 76.5 & 9.2 & 18.3 & 0 & & \\
\hline & & Female & 4.5 & 74.5 & 9.7 & 12.4 & 0 & & \\
\hline Mean & & & 4.7 & 68.3 & 8.0 & 21.5 & 23.8 & & 22 \\
\hline $\mathrm{SD}$ & & & 1.0 & 17.1 & 2.2 & 12.0 & 27.7 & & 23 \\
\hline
\end{tabular}

In the second step, assuming (Eq. 2), we get $A=$ 5.6218, $B=5.4339\left(\mathrm{R}^{2}=0.968\right)$. Then, solving the integral involved in $\varphi(t)$, we get a formula for an upper bound for the number of $M$. chilensis that $1 \mathrm{~T}$. pteneres can eat during month $t$ :

$$
\varphi(t)=\frac{31 C}{k B(1-\alpha)}\left\{[A+B(t+1)]^{(1-\alpha)}-(A+B t)^{(1-\alpha)}\right\}
$$

recalling that $C=97.4 \mathrm{~g}$ is the heaviest bivalve content found in a single duck. Using the estimated number of $T$. pteneres present at the farm during month $t$ from Table 1, we use Eq. (5) to calculate the upper bound for the number of $M$. chilensis eaten by all the ducks at the farm during month $t$. Then adding the values of $N(t)$ from March $1988(t=0)$ to February $1989(t=11)$, the upper bound for number of $M$. chilensis predated by the ducks during the year is obtained, namely $M=342571$. Finally, using $W(12)=$ $33.5 \mathrm{~g}$ as the average weight of $M$. chilensis at the end of February 1989, the upper bound for the yearly M. chilensis losses in the farm between March 1988 and February 1989 is $11.5 \mathrm{t}$.

\section{DISCUSSION}

Several studies have shown that bivalve aquaculture structures (rafts and longlines) provide good conditions for recruiting and growing mussels, additionally offering refuge to invertebrate predators, which, in turn, provide higher densities of betterquality prey for sea ducks than otherwise available in intertidal areas (Dionne et al. 2006, Žydelis et al. 2009, Cursach et al. 2011, Varennes et al. 2013). In fact, shellfish aquaculture offers a rare example in which the introduction of an industry leads to positive effects on wildlife populations (Žydelis et al. 2009). However, the negative effect of predation on mussels and the resulting losses to the industry might lead to control measures of duck populations by managers. In this context, Winter et al. (1980) described predation by Tachyeres pteneres as one of the main causes of major losses in Mytilus chilensis aquaculture: more precisely, Winter et al. (1982, 1988) asserted that depredation by this bird is the reason for major losses of shellfish less than $2.5 \mathrm{~cm}$ long from rafts and longlines, especially in austral spring (August to November), during the T. pteneres breeding season, suggesting that these birds should be controlled. Their conclusion was probably influenced by what happens in the Northern Hemisphere, where small mussels (average length $20 \mathrm{~mm}$ ) harvested on collectors are generally the most affected by predation due to the selective behaviour of some sea ducks, such as common eider Somateria mollissima (Galbraith 1992, Varennes et al. 2015). As an 
example, stock losses due to predation by eiders and scoters (Melanitta spp.) in Scotland and Canada varied between 10 and $30 \%$ of the total stock (Ross \& Furness 2000, Varennes et al. 2015). The most widely represented prey classes in the diet of sea ducks of North America are bivalves (50.1\%), followed by crustaceans $(23.7 \%)$ and gastropods (13.7\%) (Ouellet et al. 2013). Ouellet et al. (2013) estimated an increasing contribution of bivalves with increasing body mass and the opposite trend for crustaceans, concluding that, for the larger common eiders, prey preference is driven by an issue different from energy value (see also Bustnes \& Erikstad 1990, Bustnes 1998); moreover, common eiders in North America significantly vary their daily feeding time between winter and spring (Guillemette et al. 1996).

However, those observations are notoriously different from what has been described for T. pteneres in Chile, whose diet does not include more than $2.6 \%$ bivalves; according to Tobar et al. (2011), gastropods comprise up to $13.2 \%$, crustaceans up to $60.5 \%$ and chitons up to $7.9 \%$ of the diet. Moreover, in Argentina, the most frequent prey for the white-headed steamer duck T. leucocephalus are Cyrtograpsus spp., Nereididae and Mytilidae, but only up to $14 \%$. So how important is $M$. chilensis for the Magellenic steamer duck? Any animal must balance energy intake with expenditures to maintain body condition and survive, and 2 standard strategies allow a forager to achieve energy intake maximization: one is the 'quality strategy', which avoids filling the gut with low-quality food, prioritizing opportunities to feed on highly energetic prey but usually requires a longer search time; the other strategy is the 'quantity strategy', which relies on food that ensures a high encounter rate and minimal search time, with little regard for energy value (Ouellet et al. 2013). Our observations suggest that $T$. pteneres adopts the quality strategy: indeed, a diet based solely on bivalves requires a larger intake and spending a longer time engaged in feeding activities than an alternative crustacean-based diet. For bufflehead ducks Bucephala albeola (mean body mass $492 \mathrm{~g}$ ), Ouellet et al. (2013) estimated an intake of approximately $146 \%$ of their body mass if they were feeding on bivalves only, while they would need only $75 \%$ if they were feeding only on Malacostraca. However, for large sea ducks, in contrast to smaller species, the amount of food that meets their needs represents a smaller proportion of their body mass (Von Bertalanffy 1969, Ouellet et al. 2013). Since the average recorded body weight of $T$. pteneres was $4.7 \mathrm{~kg}$, close to the $5.1 \mathrm{~kg}$ recorded by Weller (1976), it is expected that prey abundance and caloric value, together with other exogenous and endogenous factors, must have an important effect on the time that $T$. pteneres spends feeding.

Guillemette et al. (1996) estimated that common eider consumption of mussels ranged between $1.78 \mathrm{~kg}$ (spring) and $2.1 \mathrm{~kg}$ (late winter) per day, spending $33-46 \%$ of their daily time on feeding, completely filling their gullet and stomach with $185 \mathrm{~g}$ of mussels in $6 \mathrm{~min}$ (Nyström \& Pehrsson 1988). Player (1971) and Varennes et al. (2015) observed that this species prefers bivalves $<30 \mathrm{~mm}$ long and cultivated ones over natural grown ones. Moreover, several authors have described common eiders feeding only during daylight and preferably during low tide (Player 1971). On the other hand, in southern Chile, M. chilensis (2.98 $\left.\mathrm{kJ} \mathrm{g}^{-1}\right)$, Choromytilus chorus $\left(2.42 \mathrm{~kJ} \mathrm{~g}^{-1}\right)$, gastropods $\left(2.2-5.4 \mathrm{~kJ} \mathrm{~g}^{-1}\right)$ and crustaceans $\left(2.7-9.8 \mathrm{~kJ} \mathrm{~g}^{-1}\right)$ are available, and in the case of $M$. chilensis, the energy value decreases as the wet weight and length increase (Duarte et al. 1980). In our study, predation on $M$. chilensis at the mussel farm was concentrated in autumn (March-May), when mussels have thinner shells and higher flesh content. These observations support the idea that, in our study area, T. pteneres has a feeding strategy oriented towards higher-quality prey such as crustaceans (Munida subrugosa, Cancer edwardsii, C. coronatus and undetermined amphipods), choosing those places where alternative options to bivalves are abundant (Tobar et al. 2011).

Diving time is linearly related to the depth at which birds are foraging, thus dives between 20 and $40 \mathrm{~s}$ are in general below $10 \mathrm{~m}$ depth (Žydelis et al. 2009). During our study, dives by T. pteneres lasted on average $29 \mathrm{~s}$ (range: 5-71 s), hence at a depth below $5 \mathrm{~m}$, in concordance with the bay depth in the study polygons (Fig. 1). This suggests that our observed ducks must have been foraging at the sea bottom searching for crustaceans, which have been observed in their diet (Tobar et al. 2011).

According to Winter et al. (1988), during 1988 the mussel farm production was approximately $720 \mathrm{t}$, and our upper bound for the $M$. chilensis losses due predation by $T$. pteneres is $11.5 \mathrm{t}$, i.e. $<1.6 \%$ of farm production; hence in Chile, the losses due to predation by sea ducks appear insignificant compared to what has been recorded in Canada and Scotland (Ross \& Furness 2000, Varennes et al. 2013).

We conclude that, in an extremely pessimistic scenario for the mussel farms' success, predation of blue mussels by Magellanic steamer ducks is at most $1.6 \%$ of the annual production. It should also be 
noted that during the study, we observed boats coming during the night into the farm area several times to steal mussels from longlines. To be more efficient, the thieves harvested only the first $2 \mathrm{~m}$ of the hanging rope, just like a duck would do, a fact of which farm owners were informed.

We also conclude that blue mussel farms in southern Chile do not promote an increase in Magellanic steamer duck populations; although they seem to provide safe resting sites for flocks, population dynamics seem to be related to other habitat variables, such as the availability of freshwater streams, the presence of safe nesting sites for pairs along the seashore and convenience of higher-quality prey like crustaceans.

Acknowledgements. An important part of this work was included in the DVM dissertation of G.M.V., supervised by the late R.P.S. The thesis was funded by what at the time was the Centro de Investigaciones Marinas of the Universidad Austral de Chile. We also thank the late Dr. Jürgen Winter for valuable logistic help during the research.

\section{LITERATURE CITED}

Bustness JO (1998) Selection of blue mussels, Mytilus edulis, by common eiders, Somateria mollissima, by size in relation to shell content. Can J Zool 76:1787-1790

Bustnes JO, Erikstad KE (1990) Size selection of common mussels, Mytilus edulis, by common eiders, Somateria mollissima: energy maximization or shell weight minimization? Can J Zool 68:2280-2283

Caldow RWG, Beadman HA, McGrorty S, Kaiser MJ, GossCustard JD, Mould K, Wilson A (2003) Effects of intertidal mussel cultivation on bird assemblages. Mar Ecol Prog Ser 259:173-183

Connolly LM, Colwell MA (2005) Comparative use of long line oysterbeds and adjacent tidal flats by waterbirds. Bird Conserv Int 15:237-255

Cursach JA, Suazo CG, Rau JR, Tobar CN, Gantz A (2011) Ensamble de aves en una mitilicultura de Chiloé, sur de Chile. Rev Biol Mar Oceanogr 46:243-247

Del Hoyo J, Elliot A, Sargatal J (1992) Handbook of the birds of the world, Vol 1. Lynx Edicions, Barcelona

* Dionne M, Lauzon-Guay J, Hamilton DJ, Barbeau MA (2006) Protective socking material for cultivated mussels: a potential non-disruptive deterrent to reduce losses to diving ducks. Aquacult Int 14:595-613

* Duarte WE, Jara F, Moreno CA (1980) Contenido energético de algunos invertebrados bentónicos de la cota de Chile y fluctuación anual en Mytilus chilensis Hupe 1854. Bolm Inst Oceanogr 29:157-162

Dzimbal KA, Jarvis RL (1982) Coastal feeding ecology of harlequin ducks in Prince William Sound, Alaska. In: Nettleship DN, Sanger GA, Springes PF (eds) Marine birds: their feeding ecology and commercial fisheries relationships. Canadian Wildlife Service, Ottawa, p 6-10

Galbraith C (1992) Mussel farms: their management alongside eider ducks. Scottish Natural Heritage, Edinburgh
Gallardi D (2014) Effects of bivalve aquaculture on the environment and their possible mitigation: a review. Fish Aquac J 5:105

Gosling E (ed) (1992) The mussel Mytilus: ecology, physiology, genetics and culture. Developments in aquaculture and fisheries science Vol 25. Elsevier, Amsterdam

G Guillemette M (1998) The effect of time and digestion constraints in common eiders while feeding and diving over blue mussel beds. Funct Ecol 12:123-131

Guillemette M, Reed A, Himmelman JH (1996) Availability and consumption of food by common eiders wintering in the Gulf of St Lawrence: evidence of prey depletion. Can J Zool 74:32-38

Martínez Piña D, González Cifuentes G (2004) Las aves de Chile, nueva guía de campo. Ediciones del Naturalista. Imprenta Salesianos, Santiago

Mondol M, Nasrin F, Nahar D (2016) Length-weight relationships, condition index and sex ratio of mussel Lamellid corrianus in a freshwater lake, northwest Bangladesh. Ribarstvo 74:172-178

Navarro JM, Winter JE (1982) Ingestion rate, assimilation efficiency and energy balance in Mytilus chilensis in relation to body size and different algal concentrations. Mar Biol 67:255-266

*Nyström KGK, Pehrsson O (1988) Salinity as a constraint affecting food and habitat choice of mussel-feeding diving ducks. Ibis 130:94-110

* Ouellet JF, Vanpé C, Guillemette M (2013) The body sizedependent diet composition of North American sea ducks in winter. PLOS ONE 8:e65667

Player PV (1971) Food and feeding habits of the common eider at Seafield, Edinburgh, in winter. Wildfowl 22: 100-106

Ribeiro S, Viddi FA, Cordeiro JL, Freitas TRO (2007) Fine-scale habitat selection of Chilean dolphins (Cephalorhynchus eutropia): interactions with aquaculture activities in southern Chiloe Island, Chile. J Mar Biol Assoc UK 87:119-128

Ross BP, Furness RW (2000) Minimising the impact of eider ducks on mussel farming. University of Glasgow

Sanger GA, Jones RD (1982) Winter feeding ecology and trophic relationships of oldsquaws and white-winged scoters on Kachemak Bay, Alaska. In: Nettleship DN, Sanger GA, Springes PF (eds) Marine birds: their feeding ecology and commercial fisheries relationships. Canadian Wildlife Service, Ottowa, p 20-28

Smith J, Shackley SE (2004) Effect of a commercial mussel Mytilus edulis lay on a sublittoral, soft sediment benthic community. Mar Ecol Prog Ser 282:185-191

Tobar C, Arriagada A, Rau J, Cursach J, Suazo C, Márquez R (2011) Dieta del pato quetru no volador (Tachyeres pteneres) en Isla Guapiquilán, Chiloé, Sur de Chile. Bol Chil Ornitol 17:103-108

Toledo OX, Zapater AE (1989) Geografía general y regional de Chile. Editorial Universitaria, Santiago de Chile

* Varennes E, Hanssen SA, Bonardelli J, Guillemette M (2013) Sea duck predation in mussel farms: the best nets for excluding common eider safely and efficiently. Aquacult Environ Interact 4:31-39

Varennes E, Hanssen SA, Bonardelli JC, Guillemette M (2015) A large molluscivore bird (common eider, Somatreria mollissima) is able to discriminate quality of blue mussels (Mytilus edulis) based on size and provenance. Can J Zool 93:655-663

Von Bertalanffy L (1969) General system theory, revised edn. George Braziller, New York, NY 
Weller MW (1976) Ecology and behaviour of steamer ducks. Wildfowl 27:45-53

Whitlach RP (1982) The ecology of New England tidal flats: a community profile. FWS/OBS-81/01. Biological Service Program, US Fish and Wildlife Service, Washington, DC

Winter JR, Navarro J, Roman C, Chaparro O, Valenzuela G (1980) Estudios bibliográficos en tres miticulturas de Chiloé (Tubildad, Huidad, Yaldad). Análisis experimental de la alimentación de Mytilus chilensis. Informe final (Mayo-Diciembre 1979). Instituto de zoología, Universidad Austral de Chile, Valdivia

Winter JR, Navarro J, Roman C, Chaparro O (1982) Programa de explotación de mitílidos. Investigación cientí-

Editorial responsibility: Pablo Arechavala-Lopez, Esporles, Illes Balears, Spain fica básica, $2^{\text {a }}$ parte. Corporación de Fomento de la Producción, Valdivia

Winter JR, Chaparro O, Toro J, Sanhueza M and others (1988) Desarrollo de la maricultura en Chiloé, Chile. Informe final. Centro de Investigaciones Marinas, Universidad Austral de Chile, Valdivia

Wobeser GA, Spraker TR (1987) Examen post-mortem. In: Schemnitz SD (ed) Manual de técnicas de gestión de vida silvestre (versión en español), 4th edn. The Wildlife Society, Bethesda, MD, p 95-104

Ǩydelis R, Esler D, Kirk M, Boyd WS (2009) Effect of offbottom shellfish aquaculture on winter habitat use by molluscivorous sea ducks. Aquat Conserv 19:34-42

Submitted: August 20, 2018; Accepted: April 23, 2019

Proofs received from author(s): June 24, 2019 